\title{
Characterization of Leaf Curl Disease of Tomato Grown in Karnataka
}

\author{
K. Priyanka ${ }^{*}$, M. S. Patil ${ }^{1}$, G. Uday ${ }^{2}$, Narayan S. Moger ${ }^{3}$ and C. Channakeshava ${ }^{4}$ \\ ${ }^{1}$ Department of Plant Pathology, ${ }^{2}$ Department of Genetics and Plant Breeding, \\ ${ }^{3}$ Institute of Agricultural Biotechnology, University of Agricultural Sciences, Dharwad \\ 580005, (Karnataka), India \\ ${ }^{4}$ Division of Plant Pathology, ICAR-Indian Institute of Horticultural Research, \\ Hesaraghatta Lake Post, Bengaluru 560089, (Karnataka), India \\ *Corresponding author
}

\author{
A B S T R A C T
}

\begin{tabular}{|l|}
\hline Ke y w o r d s \\
Tomato, Leaf curl, \\
Begomovirus, \\
ToLCV, ChiLCV, \\
CYVMV
\end{tabular}

During survey, tomato leaf samples showing leaf curl symptoms were collected from different tomato fields of Dharwad, Haveri and Kolar districts. Total nucleic acid extraction was carried out by cetyl trimethyl ammonium bromide (CTAB) method and quantified to perform polymerase chain reaction using Begomovirus group specific coat protein primers targeting the coat protein region and were sequenced. The nucleotide sequences were analyzed using the BLAST tool for which results indicated the presence of Tomato leaf curl virus (ToLCV), Croton yellow vein mosaic virus (CYVMV) and Chilli leaf curl virus (ChiLCV) that shows the association of these viruses in leaf curl symptoms in tomato obtained from the fields. The cluster analysis for all the ten sequences showed the grouping of the Chilli leaf curl virus and Tomato leaf curl virus into separate groups. Besides, the CYVMV was sub-grouped in ToLCV group. Thus this study shows the occurrence of different Begomoirus in leaf curl symptoms associated tomato growing in different regions of Karnataka.

\section{Introduction}

The Geminiviridae represent a diverse family of plant viruses that cause worldwide huge losses to economically important crops belonging to dicotyledonous and monocotyledonous group. Members of the virus family appear as twinned icosahedra particles $(\sim 18-30 \mathrm{~nm})$ which encapsulate one or two molecules of small circular single stranded DNA (ssDNA), whose size ranges between $2.5-3 \mathrm{~kb}$ each (Lazarowitz et al., 1992).

The family Geminiviridae is further divided into four genera, namely, Mastrevirus, Curtovirus, Topocuvirus and Begomovirus (Fauquet and Mayo, 2001). The ToLCV 
belongs to Begomovirus genera that in India,was first reported by Vasudeva and Samraj during the year 1948. More than 200 diseases are reported in tomato across the world, of which 40 of them are caused by viruses. Among the viral diseases, the Tomato leaf curl virus (ToLCV) disease is reported as a major constraint in tomato production. Symptoms of ToLCD include leaf curling, vein clearing and stunting, which can often lead to sterility (Saikia and Muniyappa, 1989). The losses may reach to an extent of 100 per cent during summer throughout India (Reddy et al., 2010; Raju and Patil, 2019).

The Tomato leaf curl virus (ToLCV) isolates are transmitted in nature by the whitefly Bemisia tabaci (order Hemiptera, family Aleyrodidae) in a circulative and persistent manner (Brown et al., 2012). Association of different begomovirus such as Chilli leaf curl virus, Tomato leaf curl virus and Papaya leaf curl virus causing leaf curl disease was reported to occur on Papaya host in regions of Delhi and Haryana (Pant et al., 2012) and also several other reports pertaining to such association are reported. Hence, a similar investigation was taken up to detect leaf curl disease causing viruses in tomato grown in different regions of Karnataka using Begomovirus group specific coat protein primers.

\section{Materials and Methods}

\section{Nucleic acid extraction}

Leaf curl symptoms (Fig. 1) showing tomato plants were collected from the different locations of Dharwad, Haveri and Kolar districts in Karnataka state during March 2019. Infected samples were sealed in a zipped polythene bags and stored in minicooler until stored at $-80^{\circ} \mathrm{C}$ in the laboratory. The samples were thoroughly washed to ward off the dust particles using distilled water.
The samples were labelled as D1, D2 and D3 for Dharwad samples, H1, H2, H3, H4 for Haveri samples and K1, K2, K3 for Kolar samples.

Samples were crushed separately in sterilized pestle and mortar using liquid nitrogen to collect hundred micro-gram $(\mu \mathrm{g})$ of fine powder. The fine powder was then transferred to a micro-centrifuge tube to which 750 micro-liter $(\mu \mathrm{l})$ of pre-heated CTAB extraction buffer $(100 \mathrm{mM}$ Tris $\mathrm{HCl}, 20 \mathrm{mM}$ EDTA, $1.4 \mathrm{M} \mathrm{NaCl}$ and $4 \% \mathrm{CTAB}$ ) followed by $1 \mu \mathrm{l}$ of beta mercapto-ethanol per sample. The tubes were gently inverted to mix the contents and incubated at $65^{\circ} \mathrm{C}$ for 20 minutes in hot water bath with intermittent mixing. After incubation, chloroform: isoamyl alcohol (24:1) was added with gentle mixing and centrifuged at 10000 RPM for 10 minutes. Supernatant was transferred carefully (without touching the middle layer) into a fresh tube and added equal volume of phenol: chloroform: iso-amyl alcohol (25: 24: $1)$. Further, the tubes were centrifuged at $10000 \mathrm{RPM}$ for 20 minutes at $10^{\circ} \mathrm{C}$. The supernatant was collected and dispensed into a fresh tube and added equal volume of chilled iso-propanol. The tubes were incubated overnight at $-20^{\circ}$ C. Later, centrifugation was carried out at 6000 RPM for 20 minutes at $10^{\circ} \mathrm{C}$ and decanted to retain the pellets. Ethanol wash was given to the pellets using 70 per cent ethanol prepared using nuclease free water. Later the pellets were collected by centrifuging at 6000 RPM for 3 minutes and decanting the upper liquid phase. These pellets were air dried, dissolved in TE buffer $(10 \mathrm{mM}$ EDTA and $1 \mathrm{mM}$ Tris, $\mathrm{pH}$ 8.0) and stored at $-20^{\circ} \mathrm{C}$ for further use.

\section{PCR and detection}

The extracted nucleic acid (DNA) was analysed on a 0.8 per cent pre stained ethidium bromide agarose gel and was 
quantified to 50 nano-grams per microliter using nuclease free water to perform polymerase chain reaction (PCR) using the Begomovirus group specific degenerate primers (Forward:5' GCCYATRTAYA GRAAGCCMAG 3', Reverse: 5' GGRTTD GARGCATGHGTACATG 3'; Y= C/T, H= $\mathrm{A} / \mathrm{T} / \mathrm{C}, \mathrm{R}=\mathrm{A} / \mathrm{G}, \quad \mathrm{D}=\mathrm{A} / \mathrm{G} / \mathrm{T}, \mathrm{M}=\mathrm{A} / \mathrm{C}$.) targeting the coat protein gene in a thermocycler. The PCR programme was as follows: initial denaturation at $94{ }^{\circ} \mathrm{C}$ for 5 mins, followed by 35 cycles of denaturation at $94{ }^{\circ} \mathrm{C}$ for $1 \mathrm{~min}$, annealing at $55^{\circ} \mathrm{C}$ for $1 \mathrm{~min}$, DNA synthesis at $72{ }^{\circ} \mathrm{C}$ for $2 \mathrm{~min}$. A final extension step of $72{ }^{\circ} \mathrm{C}$ for $10 \mathrm{~min}$. The PCR product was resolved in 1 per cent agarose gel. $100 \mathrm{bp}$ marker was used to identify the precised amplicon size. The PCR product was further purified and sequenced in Chromous Pvt. Ltd. for detection purpose. Sequences were analyzed in the BLAST bio-informatics tool to detect the cause of the ToLCD. Sequences were aligned using the Bioedit tool and BLAST analysis was performed to detect the cause of the ToLCD. Pairwise and multiple sequence alignment was carried out in CLUSTALW tool to construct a phylogenetic tree using the MEGAX software (Kumar et al., 2018).

\section{Results and Discussion}

PCR was performed using Begomovirus group specific coat protein primers to amplify the coat protein gene from the nucleic acid extracted from the symptomatic plant samples, to detect the presence of leaf curl virus. In the symptomatic samples, there was amplification found with amplicon size at nearly $600 \mathrm{bp}$ as shown in Fig. 2. The products were sequenced at Chromous Biotech. Pvt. Ltd. Bengaluru, aligned, and upon BLAST analysis, the output revealed a similarity hit to Chilli leaf curl virus, Tomato leaf curl virus and Croton yellow vein mosaic virus across the samples collected. Sequence homology of Dharwad samples (designated as D1, D2 and D3) depicted that CP gene sequence of D1 showed similarity of $91 \%$ to Chilli leaf curl virus detected and reported on papaya host (GenBank Accession ID: HM140365). D2 sequence homology analysis revealed a similarity of 93.19 per cent with Tomato leaf curl Karnataka virus (GenBank Accession ID: MK120481).

D3 sequence matched with Chilli leaf curl virus (GenBank Accession ID: HM140365) isolated from papaya with similarity per cent of 96. Of the Haveri samples, H1 and H4 had sequence homology Tomato leaf curl Karnataka virus (GenBank Accession ID: MK120481) with 98 and 99 per cent similarity respectively, H2 was 99 per cent similar to Croton yellow mosaic virus (GenBank Accession ID: LN886647) while H3 was 97 per cent similar to Chilli leaf curl virus (GenBank Accession ID: HM140365). Sequence of the K1 and K3 samples from Kolar district was showing 98 and 99 per cent similarity with Chilli leaf curl virus (GenBank Accession ID: HM140365) respectively, while K2 was 97 per cent similar to Tomato leaf curl Karnataka virus (GenBank Accession ID: MK120481).

Pairwise and multiple sequence alignment performed for all the ten isolates to construct a dendrogram using MEGAX tool as represented in the fig. 3, shows that the samples showing similarity to Chilli leaf curl virus falls under one taxon group while the samples showing similarity with Tomato leaf curl virus falls into a separate group along with the sample showing similarity with Croton yellow vein mosaic virus. But in the group II, the Croton yellow vein mosaic virus falls separately distinguishing itself with ToLCV showing more similarity to Tomato leaf curl virus than to the Chilli leaf curl virus.

The species belonging to the Begomovirus 
genus also have weeds as their alternate hosts (Marwal and Sahu 2014). Apart from being associated with its vector, Bemisia tabaci, they are also found to be infecting other crops of economic importance. ToLCV in association with ChiLCV is also known to induce leaf curl disease in tomato crop as well as in chilli crop belonging to different locations of Nashik, India (Chavan et al., 2013) and also in tobacco that produced symptoms such as upward curling of leaf, thickening and swelling of veins besides making the plant look yellow and stunted in appearance (Shahid et al., 2019).

ToLCV is also known to infect cucurbit crop in Iran which indicated the emergence of this strain in this country (Khameneh et al., 2016) that indicates that the virus can infect other crops other than Solanaceae family. Another report says that Tomato leaf curl Joydebpur virus infected chilli crop in Ludhiana which was detected through molecular techniques and symptoms produced were similar to that produced on tomato host (Shih et al., 2007). This Tomato leaf curl Joydebpur virus 73 to 80 per cent similar to Indian strains of chilli Begomovirus. Papaya crop of Delhi and
Haryana regions infected by leaf curl virus and showing leaf curl symptoms were detected with Chilli leaf curl virus and Tomato leaf curl virus independently indicating that papaya serves as host for other Begomovirus apart from Papaya leaf curl virus. Croton yellow vein mosaic virus was also studied to have the ability to infect tomato plants (Pramesh et al., 2013) and also other hosts including ornamentals, weeds and tobacco plants. These studies show the ability of begomoviruses to infect other economically important crops other than its host. These instances shows that leaf curl virus can infect plants within a family and also to those belonging to other family.

In the present study made to detect the leaf curl disease in tomato in three districts of Karnataka, we noticed the presence of ChiLCV and CYVMV apart from ToLCV using molecular techniques. Thus the present study made signifies that leaf curl disease in tomato can also be caused by other viruses of Geminiviridae family apart from the ToLCV and that the CYVMV is reported for the first the time in tomato from Haveri location.

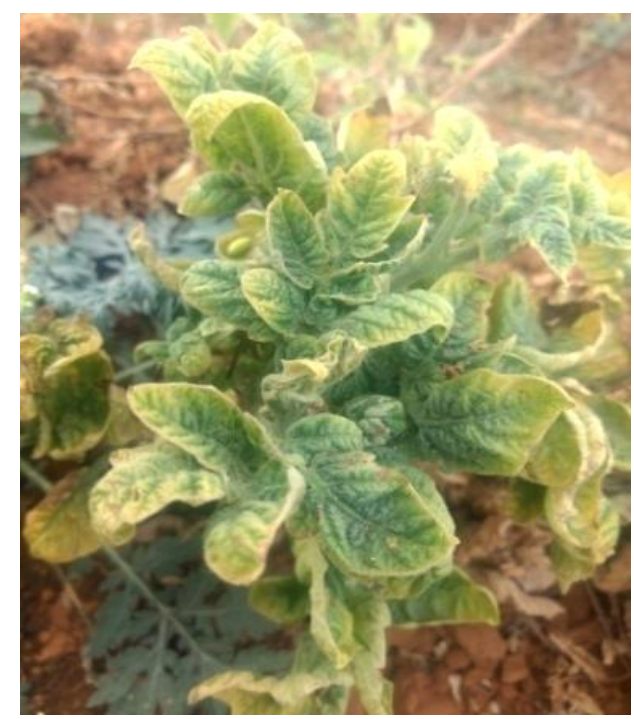

Figure.1 Leaf curl symptoms- stunted growth, chlorosis, upward curling of leaves and bushy appearance 


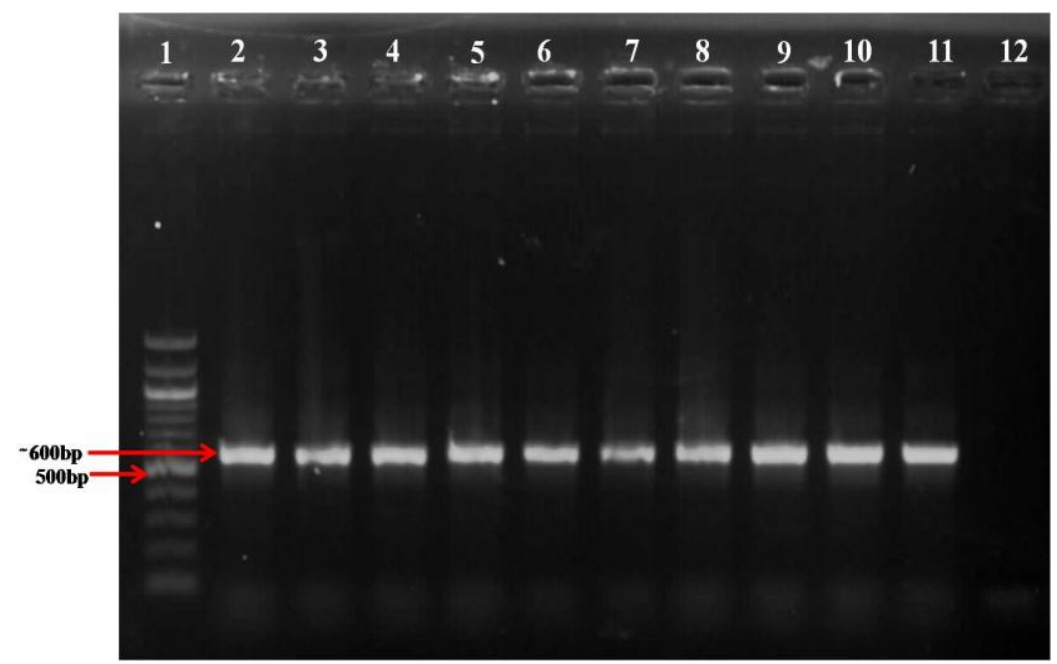

Figure.2 Positive amplification at nearly 600 bp in symptomatic plants (Lane 2-11), while no amplification in no template control (Lane 13). Lane 1 is the $100 \mathrm{bp}$ marker

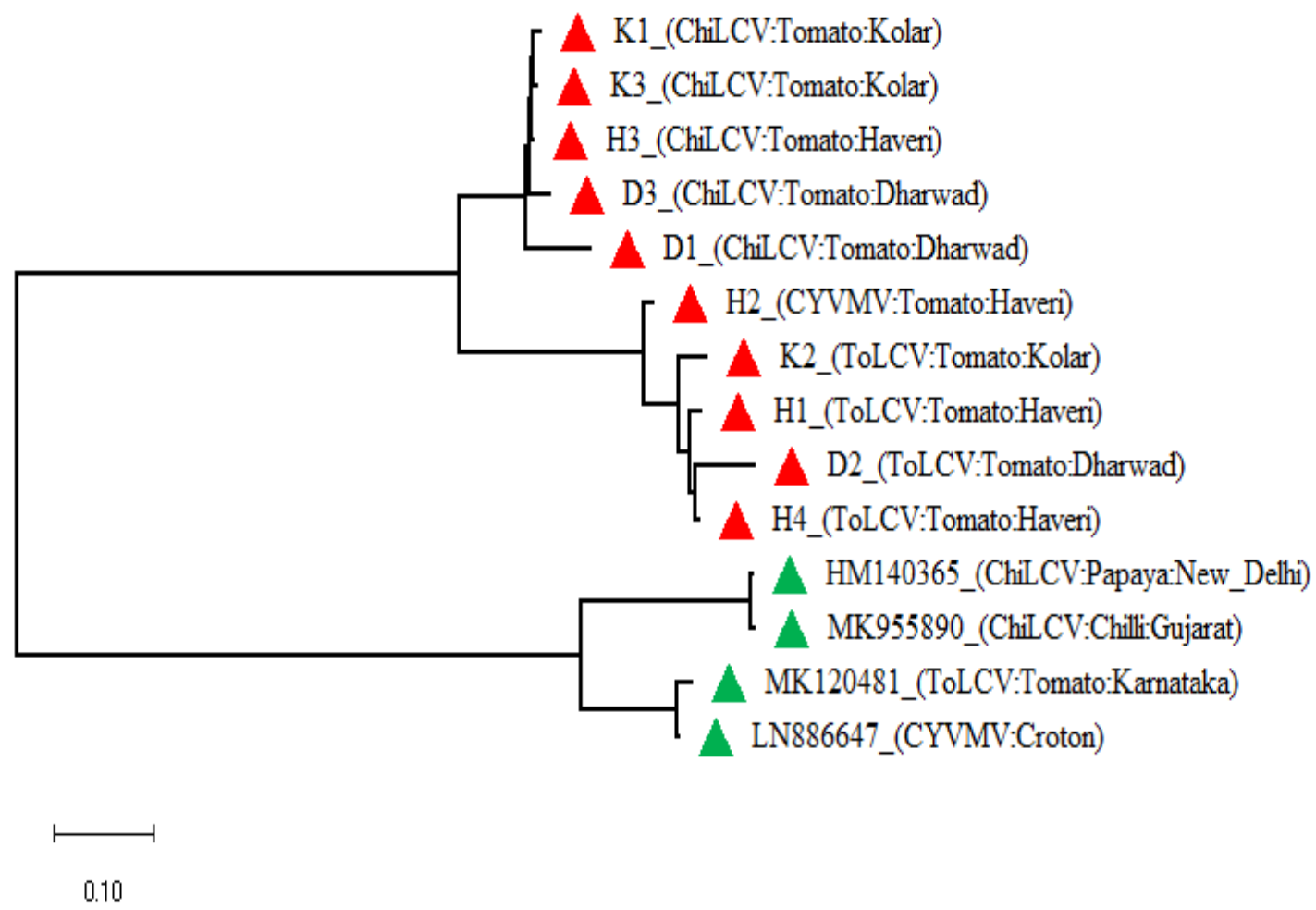

Figure.3 Phylogenetic tree determining the relationship across the samples of different locations;

The phylogeny tree was developed by CLUSTALW and MEGAX software

The above studies show the ability of begomoviruses to infect other economically important crops other than its host, i.e., ChiLCV can infect tomato apart from its main host, Chilli and CYVMV can infect tomato apart from Croton. In the present study made to detect the leaf curl disease in tomato in three districts of Karnataka, we noticed the presence of Chilli leaf curl virus and Croton yellow vein mosaic virus apart from Tomato leaf curl virus. Thus, it indicates the presence of these viruses in tomato crop grown in major tomato growing areas. 


\section{Acknowledgement}

I am grateful Dr. Narayan Moger, Institute of Biotechnology, University of Agricultural Sciences, Dharwad for providing the necessary facilities to carry out the work successfully.

\section{References}

Brown, J. K., Fauquet, C. M., Briddon, R. W., Zerbini, F. M., Moriones, E. and Castillo, J., 2012, Family Geminiviridae. In Virus Taxonomy 9th Report, Proceedings of the International Committee on Taxonomy of Viruses.

Chavan, A. K., Choudhary, R. S., Narwade, R. B. and Autade, R. H., 2013, Identification of Tomato Leaf Curl Virus (ToLCV) Strain Causing ToLCV in Tomato and Chilli. Int. J. Sci. Res., 4(8): 1713-1716.

Fauquet, C. M. and Mayo, M. A., 2001, The $7^{\text {th }}$ ICTV report. Arch. Virol., 146: 189-194.

Khameneh, S. Y., Aboutorabi, S., Shoori, M., Aghazadeh, A., Jahanshahi, P., Golnaraghi, A. and Maleki, M., 2016, Natural Occurrence of Tomato leaf curl New Delhi virus in Iranian Cucurbit Crops. Plant Pathol. J. 32(3): 201-208.

Kumar, S., Stecher, G., Li, M., Knyaz, C., and Tamura, K., 2018, MEGA X: Molecular Evolutionary Genetics Analysis across computing platforms. Molecular Biology and Evolution 35: 1547-1549.

Lazarowitz, S. G., Wu, L. C., Rogers, S. G. and Elmer, J. S., 1992, Sequence specific interaction with the viral AL1 protein identifies a Geminivirus DNA replication origin. Pl. Cell, 4: 799-809.

Marwal, A. and Sahu, A. K., 2014, Transmission and host interaction of Geminivirus in weeds. Plant Virus-Host Interaction, Chapter 7, 143-161.

Muttanna R (2016) Studies on viral diseases of cucumber. Ph. D. Thesis, Univ. Agric. Sci., Dharwad (India).

Pant, P. S., Pant, P., Mukherjee, S. K. and Leighton, S. M., 2012, Spatial and temporal diversity of begomoviral complexes in papayas with leaf curl disease. Arch Virol., 10.1007/s00705-012-1287-x

Pramesh, D., Mandal, B., Phaneendra, C. and Muniyappa, V., 2013, Host range and genetic diversity of croton yellow vein mosaic virus, a weed-infecting monopartite begomovirus causing leaf curl disease in tomato. Arch Virol., 158:531-542.

Raju, S. G. and Patil, M. S., 2019, Molecular variability of Chilli leaf curl virus in Northern Karnataka. Biochem Cell Arch 19: 343- 346.

Reddy, A. B., Patil, M. S., Krishna Reddy M. and Rajasekaram, T., 2007, Molecular detection, Survey and Management of Tomato leaf curl virus in Northern Karnataka. J Mycol Pl Pathol 40: 207- 212.

Shahid, M. S., Shafiq, M., Raza, A., Al-Sadi, A. M. and Briddon, R.W., 2019, Molecular and biological characterization of Chilli leaf curl virus and associated Tomato leaf curl betasatellite infecting tobacco in Oman. Virology Journal. 16:131

Shih, S. L., Tsai, W. S., Green, S. K. and Singh, D., 2007, First report of Tomato leaf curl Joydebpur virus infecting chilli in India. Plant Pathology (2007), 56: 341.

Vasudeva, R. S. and Sam Raj, J., 1948, A leaf curl disease of tomato. Phytopathol., 38: 364369.

\section{How to cite this article:}

Priyanka, K., M. S. Patil, G. Uday, Narayan S. Moger and Channakeshava, C. 2020. Characterization of Leaf Curl Disease of Tomato Grown in Karnataka. Int.J.Curr.Microbiol.App.Sci. 9(05): 1800-1805. doi: https://doi.org/10.20546/ijcmas.2020.905.204 